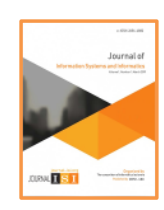

Vol. 3, No. 1, March 2021 e-ISSN: 2656-4882 p-ISSN: 2656-5935

http://journal-isi.org/index.php/isi

Published By DRPM-UBD

\title{
Sistem Informasi Geografis (SIG) Pemetaan Lokasi Pertambangan Batu Bara Berbasis Quantum GIS (Studi Kasus: PT. Hasil Bumi Kalimantan)
}

\author{
Fenando $^{1}$ \\ ${ }^{1}$ Program Studi Sistem Informasi, UIN Raden Fatah, Palembang, Indonesia \\ Email: ${ }^{1}$ fenando_uin@radenfatah.ac.id
}

\begin{abstract}
During this time, the determination of the mine coordinates location done by the fieldman of PT. Kalimantan Earth Results was using a GPS locator. Found 27 points of coal mines and 18 coal ports spread across the southern Sumatra region. At present the process of recording and mapping locations is still done conventionally, causing frequent data loss, inaccuracies in the location of mining and information about mining results are less up to date. Systematic determination of location points is needed to make the companies and customers easier to see the coal mine profiles, coal quality, find out the location of each mine, and up-to-date mining results reports via webgis The prototype model was chosen as a method in system development. As well as UML (Unified Modeling Language), Quantum GIS (Qgis) and php will be used for the designers, builders of the webgis. This research to produce a geographic information system (GIS) mapping of coal mining location points and system that has been tested using the black box testing method and has been implemented in accordance with user requirements specifications.
\end{abstract}

Keywords: GIS, Coal Location Points, QGis

\section{PENDAHULUAN}

Penerapan teknologi dan sistem informasi saat ini digunakan untuk mempermudah pengguna dalam mengelola data dalam suatu organisasi atau perusahaan [1] serta penerimaan teknologi informasi menjadi syarat utama kesuksesan implementasi teknologi informasi [2]. SIG atau yang biasa disebut dengan Sistem informasi geografis telah berkembang pesat melalui media internet. Kini semua informasi yang terdapat dalam sebuah peta akan lebih beragam karena bisa berhubungan dengan data-data lain dan salah satunya data geografis. Kebanyakan orang menggunakan webgis dengan tambahan map API google ataupun menggunakan ArcView untuk membangun sistem informasi geografis. Quantum GIS adalah Variasi terbaru dari teknologi web GIS dimana aplikasi ini 
dapat mengikuti perkembangan teknologi yang ada agar tidak tertinggal, salah satu kelebihan Guantum GIS adalah bersifat terbuka \& berbasisan komunitas resmi, setiap orang yang menggunakan Quantum GIS diizinkan dalam mengembangkan dari beberapa kelemahan dan kekurangan yang ada sehingga QGis (Quantum GIS) ini dapat menjadi sebuah aplikasi atau perangkat lunak yang jauh lebih baik lagi [3]. PT. Hasil Bumi Kalimantan merupakan perusahaan bisnis di bidang perdagangan batu bara, lokasi tambang ada di wilayah kalimantan dan sumatera selatan akan tetapi pada PT. Hasil Bumi Kalimantan belum memiliki sistem informasi geografis yang mempermudah pihak karyawan / fieldman dan customer dalam menentukan dan melihat titik lokasi tambang batu bara serta informasi yang terkait dengan hasil tambang tersebut.

Permasalaha yang terjadi selama ini, dalam menentukan lokasi koordinat tambang, para fieldman menggunakan GPS locator, ada sekitar 27 titik tambang batu bara dan 18 pelabuhan batu bara yang tersebar di wilayah sumatera selatan. Saat ini proses pencatatan dan pemetaan lokasi masih di lakukan secara konvensional dimana setelah data di dapat dari fieldman data tersebut akan di berikan ke bagian admin untuk di proses dan dalam pengolahan data lokasi dan informasi mengenai batu bara tersebut masih tersimpan di dalam microsoft word dan microsoft excel. Hal ini yang menyebabkan sering terjadinya kehilangan data, ketidak akuratan titik lokasi pertambangan serta informasi hasil tambang yang kurang $u p$-to-date yang nantinya di laporkan ke pimpinan.

Penelitian ini bertujuan untuk membangun Sistem Informasi Geografis (SIG) Pemetaan Lokasi Pertambangan Batu Bara pada PT. Hasil Bumi Kalimantan yang kedepannya memudahkan Perusahaan dan customer untuk melihat Profil tambang batu bara, kualiatas batubara, mengetahui lokais tiap-tiap tambang, pelabuhan batu bara dan laporan hasil tambang yang up to date melalui webgis.

Penelitian yang telah di lakukan oleh Tarmin [4] menghasilkan sebuah plikasi yang dapat memberikan kemudahan dalam administrasi pertanahan menggunakan google maps api. Lain lagi penelitian dari Syarif [5] menghasilkan sebuah website yang memanfaatkan google map sebagai data spasial peta dan di bangun mengguakan Bahasa pemrograma PHP dan javascript pada Kabupaten Pasaman Barat. Selanjutnya penelitian dari Sasmito [6] yang menghasilkan SIG menerapkan metode waterfall sebagai metode pengembangan perangkat lunaknya. Penelitian ini menghasilkan sebuah SIG industry kabupaten tegal menggunakan pemodelan UML (Unified Modelling Language). Penelitian berbeda dari Amnah dan Fenando [7], [8] dimana penelitian ini menggunakan metode prototype sebagai metode pengembangan sistem yang di gunakan. 


\section{METODOLOGI PENELITIAN}

Sebagai bahan pendukung bagi peneliti untuk mencari dan mengumpulkan data yang di perlukan dalam penelitian ini. Data yang dicari harus sesuai dengan tujuan peneliti. Beberapa metode yang digunakan yaitu :

1) Wawancara: Pada penelitian ini digunakan wawancara untuk memperdalam dan mengumpulkan data demi menunjang penelitian yang di lakukan [9]. Dalam melakukan penelitian ini, penulis mengumpulkan data dengan melakukan wawancara dengan pihak PT. Hasil Bumi Kalimantan, yakni Admin, Karyawan/fieldman dan Pimpinan, Selama ini untuk menentukan lokasi koordinat tambang, para karyawan menggunakan GPS locator, ada sekitar 27 titik tambang batu bara dan 18 pelabuhan batu bara yang tersebar di wilayah sumatera selatan. Saat ini proses pencatatan dan pemetaan lokasi masih di lakukan secara konvensional oleh para fieldman dimana dalam pengolahan data lokasi serta informasi mengenai batu bara tersebut di kelola oleh bagian admin dan masih tersimpan di dalam microsoft word dan excel.

2) Observasi: Pengamatan langsung terhadap alur proses yang akan berjalan yang ada di PT. Hasil Bumi Kalimantan untuk memperoleh informasi yang nantinya akan di olah kedalam Sistem Informasi Geografis (SIG) Pemetaan Lokasi Pertambangan Batu Bara Berbasis Quantum GIS (Studi Kasus : PT. Hasil Bumi Kalimantan).

3) Studi Pustaka: Pengumpulan data yang dilakukan secara langsung dari sumbersumber lain seperti buku, jurnal dan hasil penelitian yang berkaitan dengan penelitian.

\subsection{Metode Pengembangan Sistem}

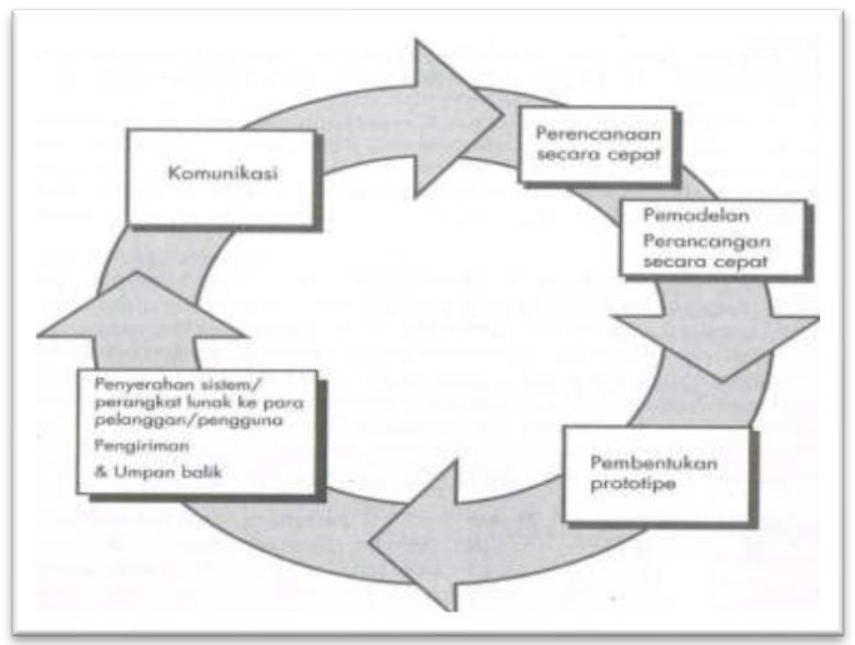

Gambar 1. Prototype Sistem 
Dalam hal ini peneliti menggunakan metode prototype seperti pada Gambar 1. Prototype bukanlah sesuatu yang lengkap, tetapi sesuatu yang harus dievaluasi \& dimodifikasi kembali. Segala bentuk perubahan bisa terjadi pada saat prototype dibuat untuk memenuhi kebutuhan pengguna/user dan pada saat bersamaam memungkinkan pengembang untuk lebih memahami kebutuhan pengguna secara lebih baik.[10] berikut adalah gambaran dari metode prototype sistem terdapat 5 (lima) tahapan di dalam metode ini:

1) Komunikasi: tahapan ini dilakukan komunikasi/wawancara dengan pihak PT. Hasil Bumi Kalimantan, yakni Admin, Karyawan/fieldman dan Pimpinan

2) Perencanaan: tahapan ini merupaan iterasi pembuatan prototype direncanakan dengan cepat.

3) Pemodelan: tahap ini dilakukan dalam suatu rancangan cepat disini penulis menggunakan UML agar terlihat oleh para pengguna akhir. Perancangan menggunakan UML dapat memindahkan kebutuhan terhadap perangkat lunak yang akan dibangun [11]

4) Konstruksi merupakan perancangan dengan cepat dalam pembuatan prototype.

5) Penyerahan: tahapan ini di lakukan untuk memberikan perangkat lunak tersebut kepada para pengguna dan mereka akan melakukan evaluasi-evaluasi tertentu terhadap prototype yang telah dibuat sebelumnya, dan nantinya mereka akan memberikan umpan balik yang akan digunakan untuk spesifikasi kebutuhan.

\section{HASIL DAN PEMBAHASAN}

\subsection{Komunikasi}

Untuk mendapatkan gambaran umum dalam membangun sistem yang baik, maka diperlukan sebuah komunikasi yang intensif dengan pimpinan, karyawan (fieldman) dan customer PT.Hasil Bumi Kalimantan. Penulis melakukan komunikasi langsung dengan pimpinan, Admin, karyawan (fieldman) dan customer dengan menggunakan metode wawancara dan observasi. PT.Hasil Bumi Kalimantan Selama ini untuk menentukan lokasi koordinat tambang, para karyawan menggunakan GPS locator, ada sekitar 27 titik tambang batu bara dan 18 pelabuhan batu bara yang tersebar di wilayah sumatera selatan. Saat ini proses pencatatan dan pemetaan lokasi masih di lakukan secara konvensional oleh para fieldman dimana dalam pengolahan data lokasi serta informasi mengenai batu bara tersebut di kelola oleh bagian admin dan masih tersimpan di dalam microsoft word dan excel. Hal ini yang menyebabkan sering terjadinya ke kehilangan data, ketidak akuratan titik lokasi pertambangan serta informasi hasil tambang yang kurang upto-date. dengan ini penentuan titik lokasi yang sistematis sangat di perlukan 
Vol. 3, No. 1, March 2021

p-ISSN: 2656-5935 http://journal-isi.org/index.php/isi e-ISSN: 2656-4882

sehingga nantinya dapat mempermudah Perusahaan dan customer untuk melihat Profil tambang batu bara, data sourcing dan kualiatas batubara, mengetahui lokais tiap-tiap tambang, pelabuhan batu bara dan laporan hasil tambang yang up-to-date melalui webgis.

\subsection{Perencanaan Secara Cepat}

Dalam tahapan perancanaan secara cepat, di lakukan untuk merencanakan kebutuhan dalam pengembangan sistem yang di butuhkan. Estimasi pengembangan sistem ini dimulai dari bulan September 2020 sampai November 2020 .

\subsection{Pemodelan Secara Cepat}

Dalam tahapan pemodelan secara cepat, tahapan ini dilakukan dengan membuat pemodelan UML (Unified Modeling Language), Berikut adalah Usecase diagram yang diusulkan :

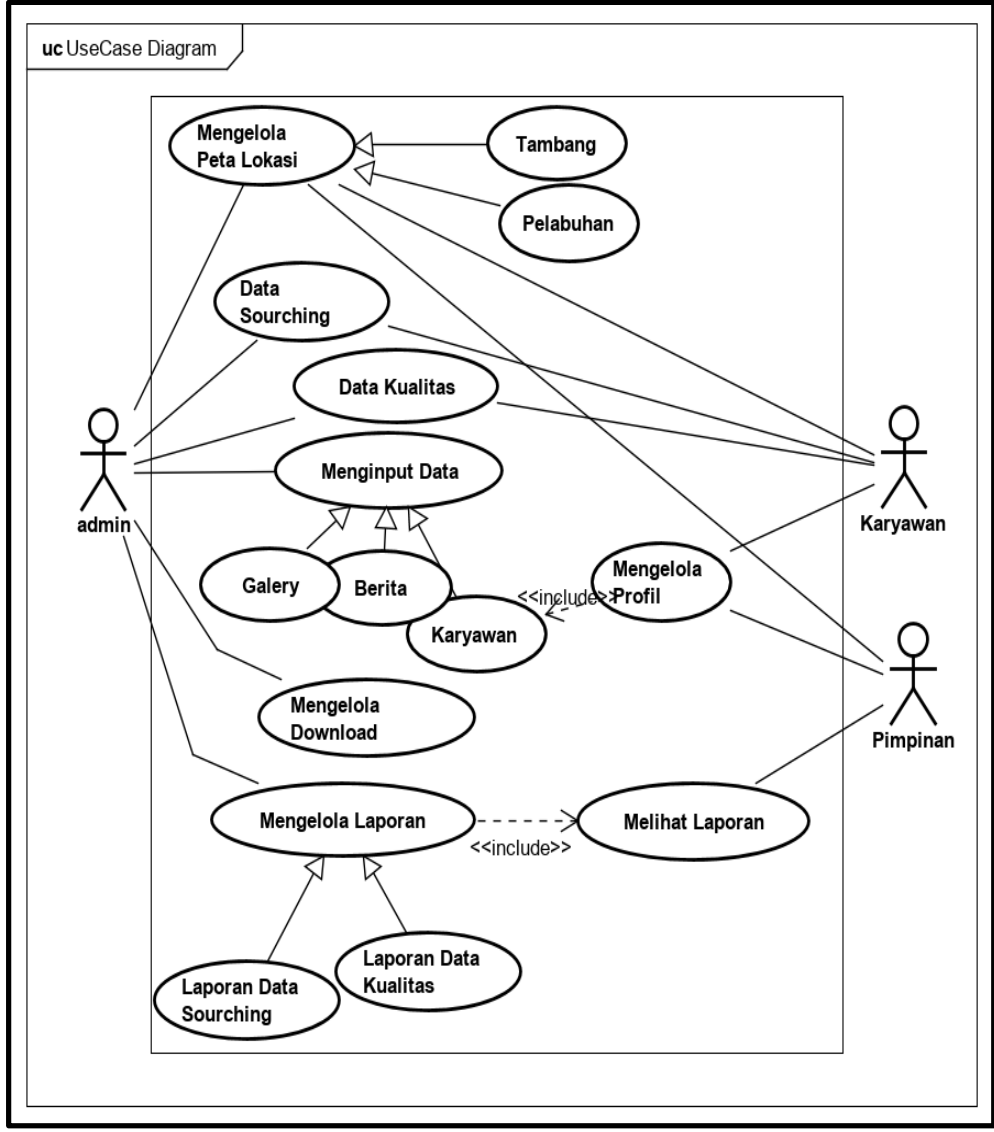

Gambar 2. Usecase diagram yang diusulkan 
Vol. 3, No. 1, March 2021

p-ISSN: 2656-5935 http://journal-isi.org/index.php/isi

e-ISSN: 2656-4882

\subsection{Pembentukan Prototipe (Konstruksi)}

Pada tahap kontruksi mengimplementasikan pemodelan, pemodelan data dan pemodelan proses yang sudah didefinisikan pada tahap sebelumnya. Pada tahapan ini dibuat dalam bentuk rancangan sebelum jadi sistem yang telah dikoding.

\subsubsection{Racangan Halaman Home}

Halaman ini merupakan rancangan halaman utama yang berisi beberapa menu yaitu menu profil, menu contact, download, menu login, peta tambang dan peta Pelabuhan.

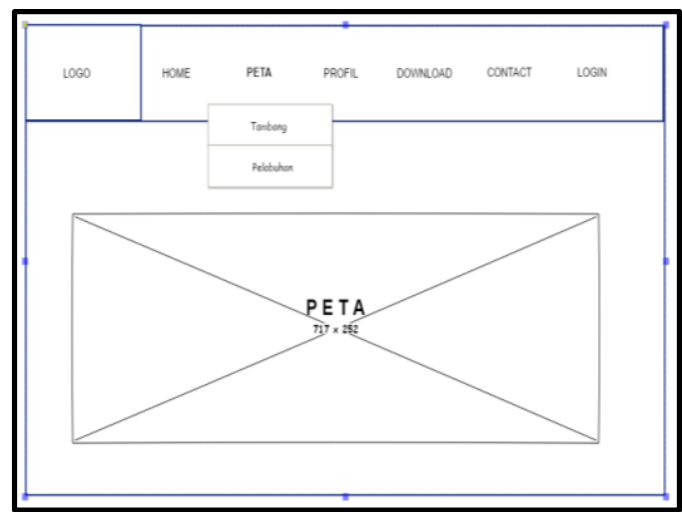

Gambar 3. Rancangan Halaman Home

\subsubsection{Rancangan Halaman Admin}

Rancangan halaman admin terdiri dari menu Peta, Data Sourcing, Data Kualitas, Input Data, Laporan, Download, Pengaturan dan Logout.

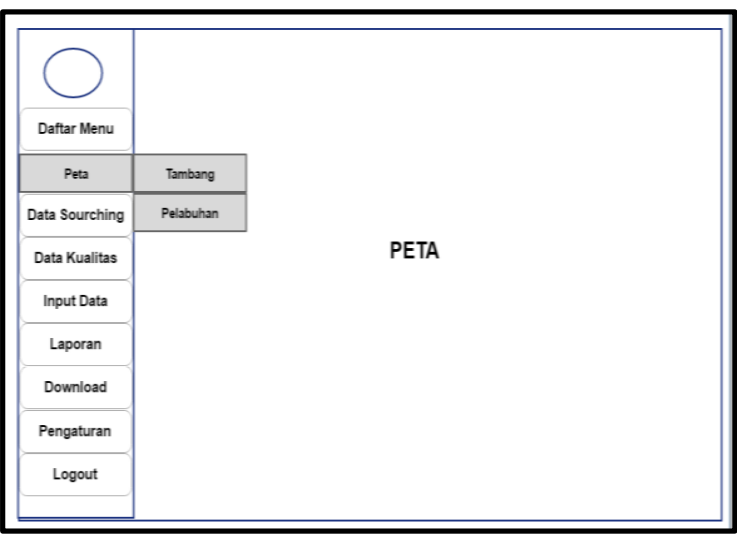

Gambar 4. Rancangan Halaman Admin 


\subsubsection{Tampilan Titik Lokasi}

Berikut ini merupakan tampilan QGis untuk menentukan titik lokasi batu bara maupun lokasi Pelabuhan.

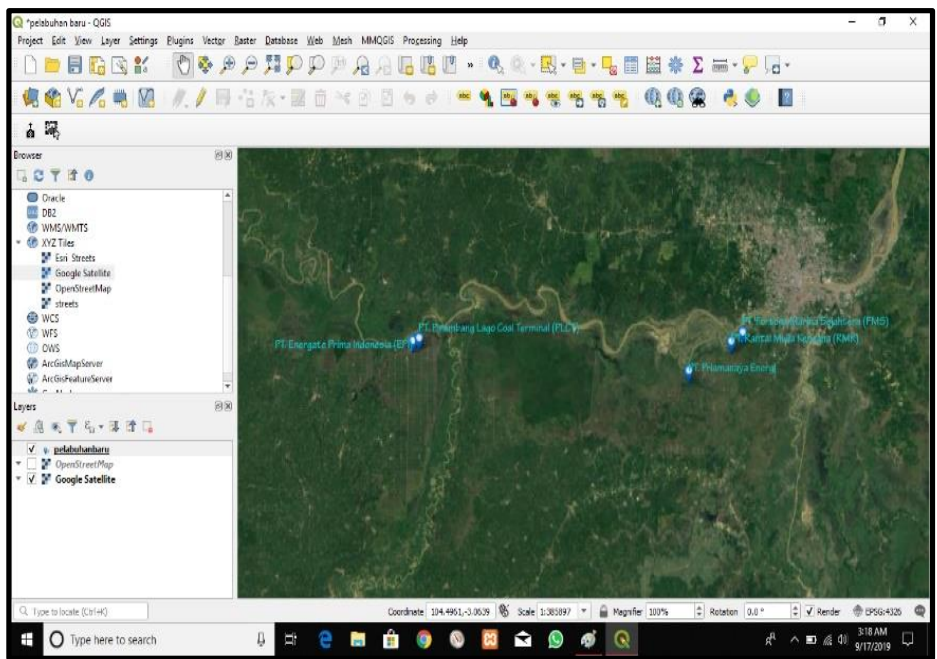

Gambar 5. Tampilan Penentuan Titik Lokasi

\subsubsection{Tampilan Export QGis}

Berikut ini merupakan Tampilan QGis untuk mengexport titik lokasi yang telah di buat kedalam format web yang nantinya akan diimport kedalam webgis.

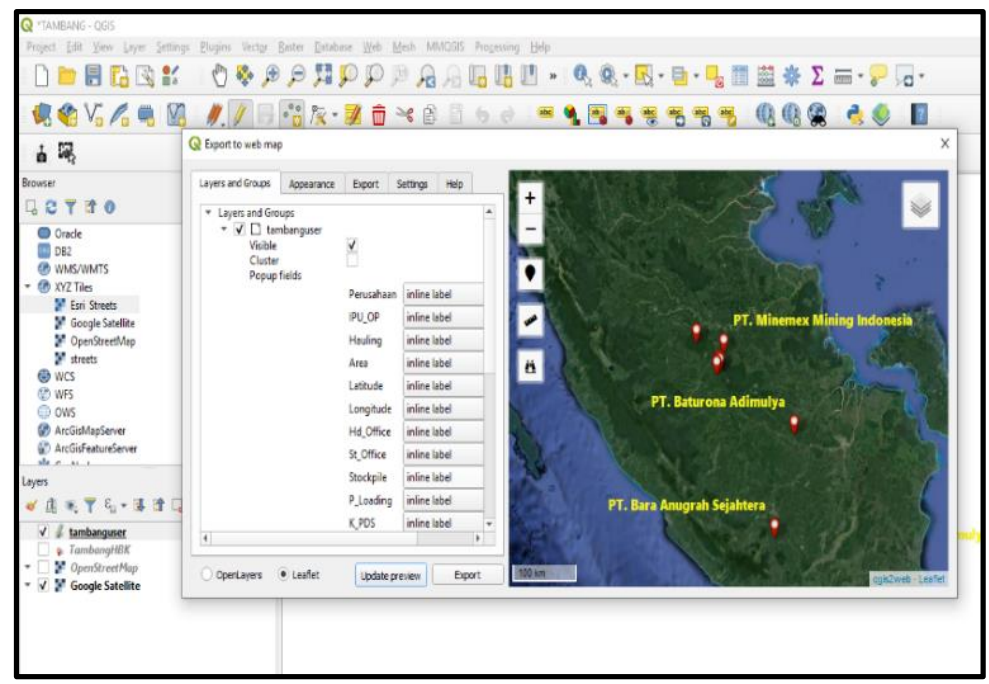

Gambar 6. Tampilan Penentuan Titik Lokasi 
Vol. 3, No. 1, March 2021

p-ISSN: 2656-5935 http://journal-isi.org/index.php/isi

e-ISSN: 2656-4882

\subsubsection{Tampilan Admin}

Berikut ini adalah Tampilan utama yang terdapat pada menu admin, disini terdapat menu home, peta, data sorcing, data kualitas, input data, laporan, download, pengaturan dan logout.

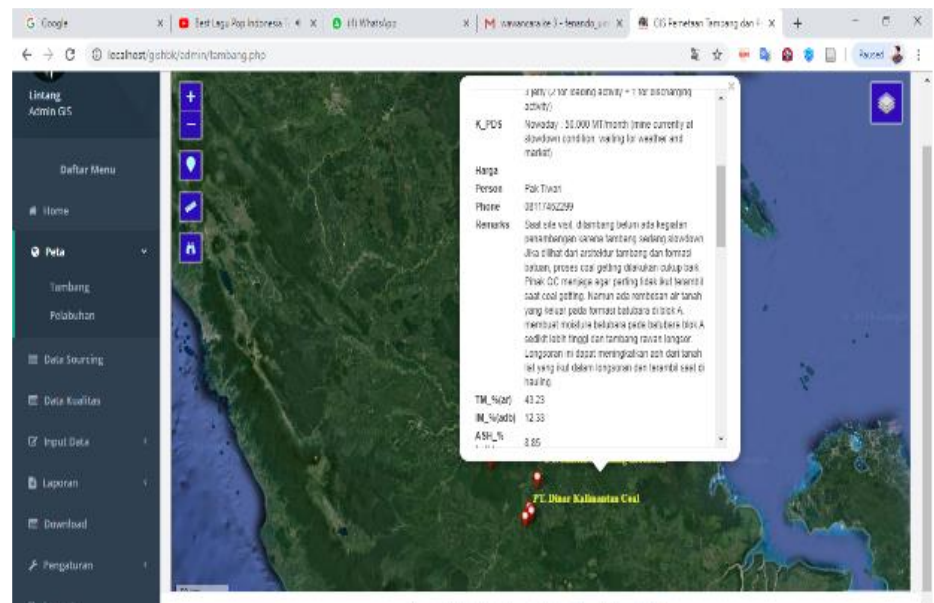

Gambar 7. Tampilan Halaman menu Admin

\subsubsection{Tampilan Menu Karyawan/Fieldman}

Tampilan halaman Karyawan adalah Tampilan utama karyawan/fieldman, pada halaman ini terdapat menu home, peta, data sourcing, data kualitas, download, pengaturan dan logout.

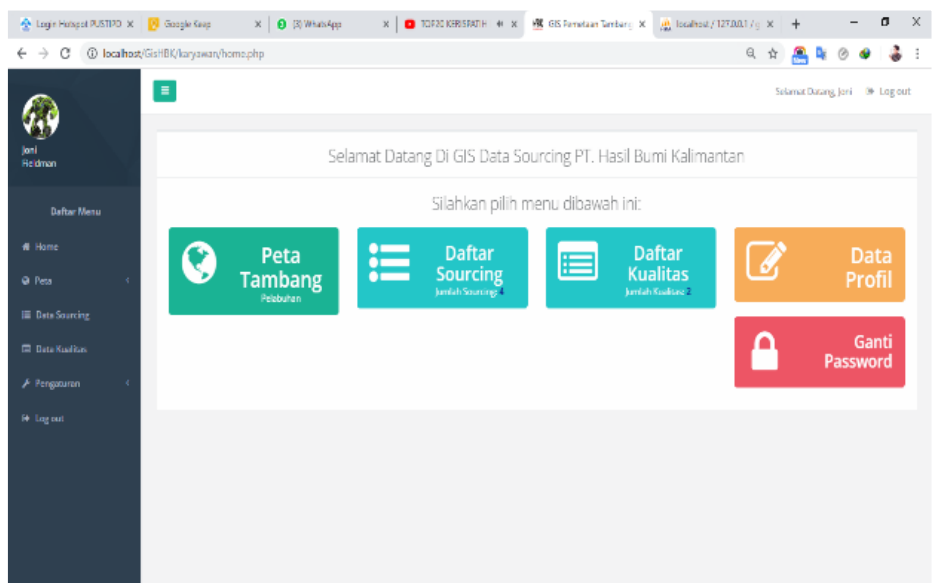

Gambar 8. Tampilan Menu Karyawan 
Vol. 3, No. 1, March 2021

p-ISSN: 2656-5935 http://journal-isi.org/index.php/isi

e-ISSN: 2656-4882

\subsubsection{Tampilan menu pimpinan}

Berikut ini merupakan Tampilan yang terdapat pada menu utama pimpinan, pada menu ini terdapat menu home, peta, laporan data sorcing, laporan data kualitas, pengaturan dan logout.

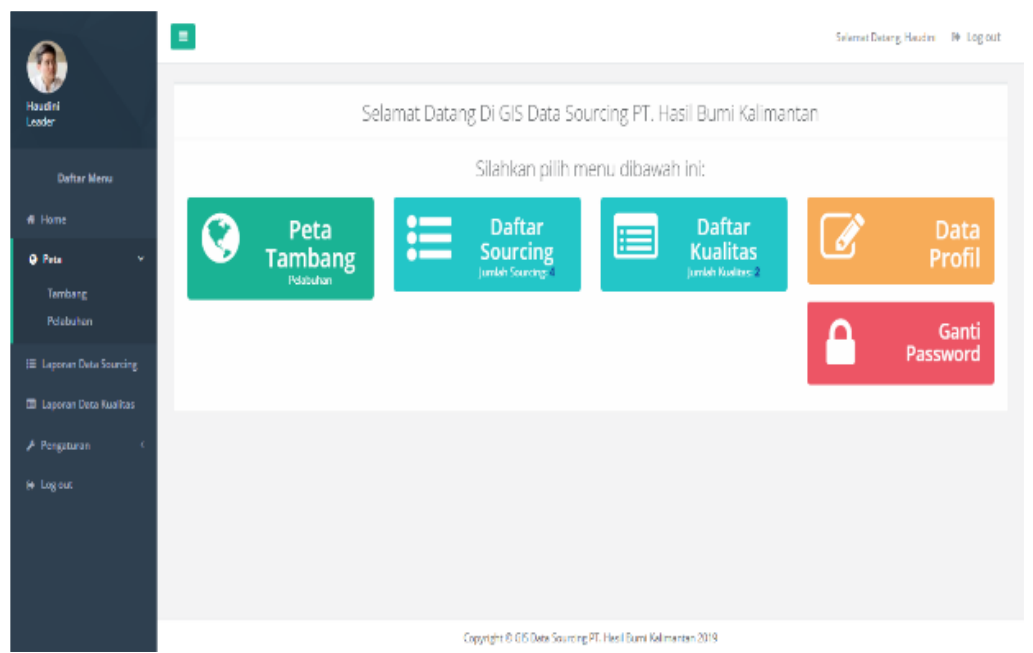

Gambar 9. Tampilan Halaman Menu Pimpinan

\subsubsection{Tampilan menu laporan sourcing}

Tampilan menu laporan data sourcing pada login pimpinan terdapat tombol cetak
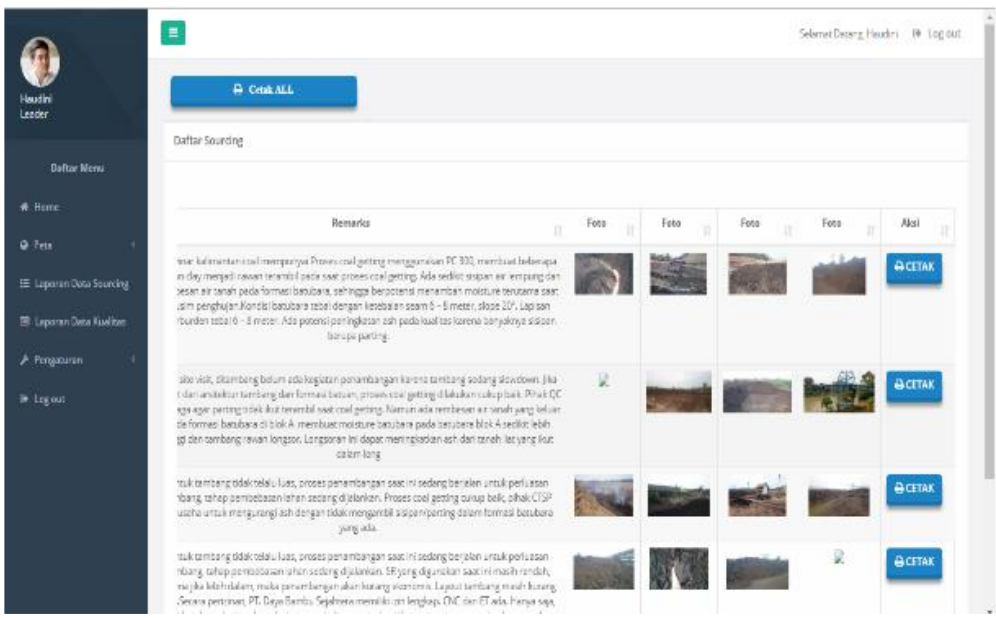

Gambar 10. Tampilan Halaman laporan data sourcing pimpinan 


\subsection{Penyerahan Sistem dan Umpan Balik}

Tahap penyerahan sistem bertujuan untuk mendapatkan umpan balik dari PT. Hasil Bumi Kalimantan Setiap prototype yang baru akan diserahkan untuk mengetahui sudah sejauh mana sistem informasi geografis memenuhi kebutuhan dari perusahaan tersebut. Dengan menggunakan metode prototype akan mengalami beberapa iterasi sampai SIG sesuai dengan kebutuhan PT. Hasil Bumi Kalimantan. Apabila SIG ini telah baik dan sesuai dengan kebutuhan PT. Hasil Bumi Kalimantan maka akan diserahkan secara penuh kepada PT. Hasil Bumi Kalimantan.

\subsubsection{Pengujian Sistem}

Pengujian yang dilakukan pada sistem informasi geografis ini menggunakan Black Box Testing. Tujuannya untuk mengetahui fungsi, masukan, dan keluaran dari sistem yang dibangun telah sesuai dengan spesifikasi sistem yang dibutuhkan [12]. Berikut ini pengujian sistem yang telah dilakukan dan diwakilkan dengan menampilkan pengujian yang telah dilakukan oleh admin, sebagian pengujian dapat dilihat pada Tabel 1.

Tabel 1. Hasil Akhir pengujian oleh Admin

\begin{tabular}{|c|c|c|c|c|}
\hline No & $\begin{array}{c}\text { Fungsi } \\
\text { yang diuji }\end{array}$ & Skenario & Hasil yang diharapkan & $\begin{array}{c}\text { Hasil } \\
\text { pengujian }\end{array}$ \\
\hline 1 & $\begin{array}{l}\text { Fungsi } \\
\text { Login }\end{array}$ & $\begin{array}{l}\text { Admin } \\
\text { memasukkan } \\
\text { username dan } \\
\text { password }\end{array}$ & $\begin{array}{l}\text { Admin masuk ke Tampilan } \\
\text { sistem dan menampilkan } \\
\text { pemberitahuan bahwa login } \\
\text { berhasil }\end{array}$ & Berhasil \\
\hline 2 & $\begin{array}{l}\text { Fungsi } \\
\text { Menu GIS }\end{array}$ & $\begin{array}{l}\text { Admin masuk } \\
\text { ke menu gis }\end{array}$ & $\begin{array}{l}\text { Admin masuk ke Tampilan } \\
\text { sistem yang menampilkan } \\
\text { menu GIS }\end{array}$ & Berhasil \\
\hline 3 & $\begin{array}{l}\text { Fungsi } \\
\text { Search }\end{array}$ & $\begin{array}{l}\text { Masuk pada } \\
\text { menu GIS, } \\
\text { kemudian pilih } \\
\text { menu } \\
\text { pencarian }\end{array}$ & $\begin{array}{l}\text { Sistem akan menampilkan } \\
\text { pencarian sesuai dengan input } \\
\text { kata yang di tulis }\end{array}$ & Berhasil \\
\hline 4 & $\begin{array}{l}\text { Fungsi } \\
\text { Menu GIS } \\
\text { tambang }\end{array}$ & $\begin{array}{l}\text { Pilih lokasi } \\
\text { pelabuhan atau } \\
\text { tambang yang } \\
\text { ingin dilihat }\end{array}$ & $\begin{array}{l}\text { Sistem akan menampilkan } \\
\text { Pemetaan lokasi tambang atau } \\
\text { pun pelabuhan dan info } \\
\text { terkait meliputi atribut titik } \\
\text { lokasi, jarak, nama kualitas. }\end{array}$ & Berhasil \\
\hline 5 & $\begin{array}{l}\text { Fungsi } \\
\text { Menu GIS } \\
\text { pelabuhan }\end{array}$ & $\begin{array}{l}\text { Pilih lokasi } \\
\text { tambang yang } \\
\text { ingin dilihat }\end{array}$ & $\begin{array}{l}\text { Sistem akan menampilkan } \\
\text { Pemetaan lokasi pelabuhan } \\
\text { dan info terkait meliputi } \\
\text { atribut titik lokasi, nama } \\
\text { kualitas. dsb }\end{array}$ & Berhasil \\
\hline
\end{tabular}


Vol. 3, No. 1, March 2021

\begin{tabular}{|c|c|c|c|c|}
\hline \multicolumn{2}{|c|}{ p-ISSN: 2656-5935 } & \multicolumn{2}{|c|}{ http://journal-isi.org/index.php/isi } & e-ISSN: $2656-4882$ \\
\hline 6 & $\begin{array}{l}\text { Fungsi } \\
\text { button Zoom } \\
\text { out dan } \\
\text { Zoom In }\end{array}$ & $\begin{array}{l}\text { Pilih tombol } \\
\text { button }\end{array}$ & $\begin{array}{l}\text { Sistem akan otomatis } \\
\text { memperbesar/memperkecil } \\
\text { peta. }\end{array}$ & Berhasil \\
\hline 7 & $\begin{array}{l}\text { Fungsi } \\
\text { button } \\
\text { Pengaturan }\end{array}$ & $\begin{array}{l}\text { Pilih tombol } \\
\text { button }\end{array}$ & $\begin{array}{l}\text { Sistem akan menampilkan } \\
\text { menu ganti password dan } \\
\text { data profil }\end{array}$ & Berhasil \\
\hline 8 & $\begin{array}{l}\text { Fungsi } \\
\text { Menu data } \\
\text { sourcing }\end{array}$ & $\begin{array}{l}\text { Pilih tombol } \\
\text { tambah data } \\
\text { sourcing }\end{array}$ & $\begin{array}{l}\text { Sistem akan menampilkan } \\
\text { field-filed yang akan di } \\
\text { tambahkan kedalam sistem }\end{array}$ & Berhasil \\
\hline 9 & $\begin{array}{l}\text { Fungsi } \\
\text { tombol } \\
\text { update data } \\
\text { sourcing }\end{array}$ & $\begin{array}{l}\text { Pilih tombol } \\
\text { update data } \\
\text { sourcing }\end{array}$ & $\begin{array}{l}\text { Sistem akan mempilkan form } \\
\text { data sourcing yg akan di } \\
\text { update }\end{array}$ & Berhasil \\
\hline 10 & $\begin{array}{l}\text { Fungsi } \\
\text { tombol } \\
\text { delete data } \\
\text { sourcing }\end{array}$ & $\begin{array}{l}\text { Pilih tombol } \\
\text { delete data } \\
\text { sourcing }\end{array}$ & $\begin{array}{l}\text { Sistem akan menghapus data } \\
\text { soucing yang telah di pilih }\end{array}$ & Berhasil \\
\hline 11 & $\begin{array}{l}\text { Fungsi } \\
\text { menu data } \\
\text { kualitas }\end{array}$ & $\begin{array}{l}\text { Pilih tombol } \\
\text { tambah data } \\
\text { kualitas }\end{array}$ & $\begin{array}{l}\text { Sistem akan menampilkan } \\
\text { field-filed yang akan di } \\
\text { tambahkan kedalam sistem }\end{array}$ & Berhasil \\
\hline 12 & $\begin{array}{l}\text { Fungsi } \\
\text { menu input } \\
\text { data }\end{array}$ & $\begin{array}{l}\text { Pilih menu } \\
\text { input data }\end{array}$ & $\begin{array}{l}\text { Sistem akan menampilkan } \\
\text { beberapa submenu terdiri dari } \\
\text { menu karyawan, berita, } \\
\text { gallery, dan profil }\end{array}$ & Berhasil \\
\hline 13 & $\begin{array}{l}\text { Fungsi } \\
\text { menu } \\
\text { karyawan }\end{array}$ & $\begin{array}{l}\text { Pilih tombol } \\
\text { tambah, update } \\
\text { dan delete data } \\
\text { karwayan }\end{array}$ & $\begin{array}{l}\text { Sistem akan menampilkan } \\
\text { form data karyawan yang akan } \\
\text { di inputkan, di update dan } \\
\text { bias juga menghapus data }\end{array}$ & Berhasil \\
\hline 14 & $\begin{array}{l}\text { Fungsi } \\
\text { menu Berita }\end{array}$ & $\begin{array}{l}\text { Pilih tombol } \\
\text { tambah, update } \\
\text { dan delete data } \\
\text { berita }\end{array}$ & $\begin{array}{l}\text { Sistem akan menampilkan } \\
\text { form data input dan update } \\
\text { berita dan bias juga } \\
\text { menghapus data }\end{array}$ & Berhasil \\
\hline 15 & $\begin{array}{l}\text { Fungsi } \\
\text { menu } \\
\text { Galeri }\end{array}$ & $\begin{array}{l}\text { Pilih tombol } \\
\text { tambah dan } \\
\text { delete galeri }\end{array}$ & $\begin{array}{l}\text { Sistem akan menampilkan } \\
\text { form data input dan hapus } \\
\text { galeri }\end{array}$ & Berhasil \\
\hline 16 & $\begin{array}{l}\text { Fungsi } \\
\text { menu Profil }\end{array}$ & $\begin{array}{l}\text { Pilih update } \\
\text { data profil } \\
\text { perusahaan }\end{array}$ & $\begin{array}{l}\text { Sistem akan menampilkan } \\
\text { form update data update } \\
\text { profil perusahaan }\end{array}$ & Berhasil \\
\hline 17 & $\begin{array}{l}\text { Fungsi } \\
\text { menu } \\
\text { Download }\end{array}$ & $\begin{array}{l}\text { Pilih tombol } \\
\text { tambah, update } \\
\text { dan delete data } \\
\text { download }\end{array}$ & $\begin{array}{l}\text { Sistem akan menampilkan } \\
\text { form data input dan update } \\
\text { download dan bias juga } \\
\text { menghapus data }\end{array}$ & Berhasil \\
\hline 18 & $\begin{array}{l}\text { Fungsi } \\
\text { menu } \\
\text { pengaturan }\end{array}$ & $\begin{array}{l}\text { Pilih menu } \\
\text { ganti password }\end{array}$ & $\begin{array}{l}\text { Sistem akan menampilkan } \\
\text { form ganti password }\end{array}$ & Berhasil \\
\hline
\end{tabular}


Pengujian ini setidaknya dilakukan sebanyak 3 (tiga) kali oleh pengguna sampai akhirnya seluruh fungsi yang diujikan dapat berjalan tanpa ada gagal sistem.

\section{SIMPULAN}

Setalah dilakukan penelitian maka dapat diambil kesimpulan antara lain, Telah berhasil dibangun sebuah Sistem Informasi Geografis (SIG) Pemetaan Lokasi Pertambangan Batu Bara PT. Hasil Bumi Kalimantan Yang memudahkan perusahaan dan customer untuk melihat Profil tambang batu bara, kualiatas batubara, mengetahui lokais tiap-tiap tambang, pelabuhan batu bara dan laporan hasil tambang yang up-to-date melalui webgis. Sistem ini telah diuji menggunakan metode pengujian black box Testing dan telah diimplementasikan sesuai dengan spesifikasi kebutuhan pengguna.

\section{DAFTAR PUSTAKA}

[1] C. E. Gunawan and F. Fenando, "Pengukuran Keamanan Informasi Menggunakan Indeks Keamanan Informasi (KAMI) Studi Kasus di PUSTIPD UIN Raden Fatah Palembang," JUSIFO J. Sist. Inf., vol. 4, no. 2, pp. 121-132, Dec. 2018, doi: 10.19109/jusifo.v4i2.4107.

[2] M. S. R. Pratama, R. Santi, and F. Fenando, "Analisis Penerimaan Sistem Informasi K Exam Karate Lemkari di Lemkari Sumatera Selatan Dengan Menggunakan Technology Acceptance Model," J. Inf. Technol. Ampera, vol. 1, no. 1, Art. no. 1, Apr. 2020, doi: 10.51519/journalita.volume1.isssue1.year2020.page12-28.

[3] E. Budiyanto, Sistem informasi geografis dengan Quantum GIS. Andi Offset, 2016.

[4] T. Abdulghani and E. Ubaedilah, "Analisis dan perancangan sistem informasi geografis sebaran tanah penduduk (studi kasus desa tanjungasari, kab. Cianjur)," vol. 2, p. 12, 2018.

[5] A. Syarif, "SISTEM INFORMASI GEOGRAFIS SARANA PADA KABUPATEN PASAMAN BARAT," vol. 4, no. 2, p. 11, 2016.

[6] G. W. Sasmito, "Penerapan Metode Waterfall Pada Desain Sistem Informasi Geografis Industri Kabupaten Tegal," J. Inform. J. Pengemb. IT, vol. 2, no. 1, Art. no. 1, Jan. 2017, doi: 10.30591/jpit.v2i1.435.

[7] Amnah -, "Rancang Bangun Sistem Informasi Geografis Penyebaran Lokasi Hutan Lindung Pada Provinsi Lampung," Journal:eArticle, Darmajaya Informatics and Business Institute, 2016.

[8] F. Fenando, "Implementasi E-Commerce Berbasis Web pada Toko Denia Donuts Menggunakan Metode Prototype," JUSIFO J. Sist. Inf., vol. 6, no. 2, pp. 66-77, Dec. 2020, doi: 10.19109/jusifo.v6i2.6532.

[9] Sugiyono, P. D, Metode Penelitian Bisnis: Pendekatan Kuantitatif, Kualitatif, Kombinasi, dan R\&D. Bandung: CV. Alfabeta, 2017.

[10] R. S. Presman, Rekayasa Perangkat Lunak (7th ed.), 7th ed. Andi, 2012. 
[11] D. W. T. Putra and R. Andriani, "Unified Modelling Language (UML) dalam Perancangan Sistem Informasi Permohonan Pembayaran Restitusi SPPD," J. Teknolf, vol. 7, no. 1, p. 32, Apr. 2019, doi: 10.21063/jtif.2019.V7.1.32-39.

[12] T. Hidayat and M. Muttaqin, "Pengujian Sistem Informasi Pendaftaran dan Pembayaran Wisuda Online menggunakan Black Box Testing dengan Metode Equivalence Partitioning dan Boundary Value Analysis,” vol. 6, p. 5, 2018. 